\title{
Gender in het huidige sociologieonderwijs: Thema en/of perspectief?
}

Niels Spierings \& Marie-Louise Janssen

\author{
TVGN 19 (2): 165-185
}

DOI: 10.5117/TVGN2016.2.SPIE

\begin{abstract}
In this educational memo, we will explore in which measure and form gender and sexuality studies is a part of the Dutch sociology curriculum, and in particular the present situation at the University of Amsterdam and Radboud University. Both universities have a rich history in gender studies, but represent different perspectives within sociology. Looking at both curricula, a general image emerges of social-cultural man-woman differences and sexuality as themes, but these are not anchored in the final attainment level, which makes the individual role of the lectures quite big. In the required readings there is hardly any attention for a gender perspective in which students learn to apply gender as an analytical category. However, both universities offer a wide selection of specialisation courses to interested students. Here, opportunities seem to be missed to apply gender studies within sociology as a bridge between different disciplines and methodological approaches. This exploration ends with a brief outline of the further anchoring of gender and sexuality studies in the sociology curriculum on basis of three educational strategies.
\end{abstract}

Keywords: sociology, education, gender, sexuality

\section{Introductie: sociologie}

De Nederlandse sociologie is wel omschreven als 'de speurtocht naar de elementaire deeltjes en de structuur van de globalisering en individualisering' (Smollenaars, 2006). Daarbij worden drie of vier hoofdvragen of -thema's onderkend. Het eerste thema is dat van de sociale ongelijkheid: wie 
krijgt wat en waarom? De tweede van cohesie: waarom leven mensen wel of niet in verbondenheid en vreedzaamheid samen? De derde van rationalisering: hoe rationeel handelen mensen en instituties en wat is de invloed van technologisering op onze maatschappij? Ten slotte, voegen sommigen identiteit toe als vierde thema: wie zijn wij? (Raub in Smollenaars, 2006; Ultee, Arts \& Flap, 2003; Ultee in Spiering, 1997).

Gendercomponenten en deelvragen zijn gemakkelijk bij elke van de vier sociologische thema's te bedenken omdat ze raken aan machts- en ongelijkheidsvraagstukken in de samenleving. Niet verrassend doet menig socioloog in Nederland dan ook onderzoek naar genderthema's, bijvoorbeeld hoe instituties en maatschappelijke normen 'mannelijke' en 'vrouwelijke' gedragingen en attitudes beïnvloeden. Binnen genderstudies wordt gender echter niet alleen als een empirische categorie beschouwd, maar ook als een theoretisch perspectief dat inzicht verschaft in hoe man-vrouwongelijkheid wordt geproduceerd. Het gaat dan om de sociaal-culturele interpretatie van sekse en gender als theoretisch concept om over machtsrelaties na te denken, bijvoorbeeld in onderzoek naar sociale instellingen in een samenleving en de rol die deze spelen in het in stand houden van sociale ongelijkheid. Zoals historica Joan Scott zegt: 'gender is the perceptual lens through which we are taught the meanings of male/female, masculine/feminine' (2013: 66). Gender biedt op deze manier een unieke analytische lens binnen academisch onderwijs dat bijdraagt aan een beter begrip van hoe sekse, seksualiteit en andere categorieën van verschil, zoals etniciteit en sociale klasse, de ervaringen van een individu of een groep vormen. Een genderperspectief stelt ons in staat om andere vragen te stellen en te beantwoorden, zoals verschillen in macht en controle, en inzicht in uitsluitingsprocessen op grond van sekse, gender en seksualiteit.

In deze bijdrage stellen we de vraag centraal in hoeverre gender en seksualiteit - al dan niet onder die noemers - als thema en perspectief in het onderwijs in de Nederlandse sociologie zijn ingebed en hoe. In lijn met bovenstaande bespreking zullen we een onderscheid maken tussen gender als thematiek - behandelt een opleiding bijvoorbeeld gendernormen met betrekking tot arbeidsdeling en onderwerpen als man-vrouwongelijkheid - en gender als perspectief - in welke mate wordt aan studenten kennis overgedragen zodat zij zelf met een theoretische genderlens het ontstaan van machtsongelijkheid en de reproductie van machtspatronen kunnen analyseren? We gebruiken in deze bijdrage gender dus als een overkoepelende term waaronder zowel de thematiek als het perspectief te plaatsen zijn. We stellen doelbewust de beschrijvende vraag hier voorop. Verklarende vragen over de oorzaken en impact van de huidige situatie, bijvoorbeeld gekoppeld aan het 
ontstaan en voortbestaan van vrouwen/genderstudies, vergen een uitgebreidere behandeling en kunnen we hooguit aanstippen. Dergelijke vragen kunnen bovendien preciezer beantwoord worden door eerst de verschillende bijdragen aan dit themanummer naast elkaar te leggen. Een antwoord op de beschrijvende vraag is immers onderliggend aan deze andere vragen.

We zullen het onderwijs aan twee universiteiten onder de loep nemen: de sociologieopleidingen aan de Universiteit van Amsterdam (UvA) en de Radboud Universiteit Nijmegen (RU). In het bijzonder zullen we kijken naar de eindtermen van deze opleidingen, de cursusbeschrijvingen van de verplichte curricula, en het aanbod aan keuzevakken, minores en extra curriculair onderwijs. De nadruk ligt op de vraag in hoeverre genderkennis wordt overgedragen aan studenten. Drie specifieke aandachtspunten daarbij zijn: (1) in hoeverre is in de formele opleidingstructuur de inclusie van gender vastgelegd; (2) in welke mate is gender als thema en/of als perspectief geïntegreerd in het onderwijs; en (3) welke mogelijkheden hebben studenten om zelf genderkennis te vergaren of verder te verdiepen waar dit niet standaard wordt aangeboden.

De vergelijking tussen RU en UvA is om in ieder geval twee redenen interessant. Allereerst zijn de RU en UvA de twee most-likely cases (Gerring, 2007:115-22) voor een relatief sterke incorporatie van gender in de curricula. Beide universiteiten huisvest(t)en van oudsher prominente academici en instituten in vrouwen- en genderstudies. Voor de Universiteit Utrecht (UU) geldt dit uiteraard ook, maar aan de UU staat genderstudies dichter bij letteren, terwijl aan de UvA en de RU er altijd een sterke connectie met sociale wetenschappen is geweest. We zouden dus kunnen zeggen: als we geen sterke inbedding van genderstudies in het sociologieonderwijs aan de UvA en RU vinden, dan zullen we het waarschijnlijk ook niet in de andere sociologiecurricula aantreffen. Ten tweede zijn de twee cases te beschouwen als diverse cases (Gerring, 2007:97-101). Ze vertegenwoordigen de twee verschillende scholen in de Nederlandse sociologie: de verklarende sociologie (RU) en de begrijpende sociologie (UvA) - ook wel als figuratief of verhalend geduid (zie Schnabel, 2002; Van El, 2002) ${ }^{1}$. Voor alle duidelijkheid, behoeft gezegd te worden dat op basis van de hieronder volgende analyse geen algemene conclusies over de integratie van genderonderwijs in de Nederlandse sociologie getrokken kunnen worden. Daar waar wij meer algemene patronen observeren, dient dit voornamelijk als een verdere afstelling van de lens waarmee ook naar andere sociologieopleidingen gekeken kan worden. Meer algemeen kunnen we stellen dat deze bijdrage als het startpunt van een nieuw debat is bedoeld en daarmee hopelijk een inspiratie vormt voor verdere analyse van de integratie van genderonderwijs in de Nederlandse sociologie. 


\section{Radboud Universiteit Nijmegen}

De Radboud Universiteit biedt drie opleidingen aan verzorgd door de afdeling sociologie: de Bachelor 'Sociologie', de Master 'Sociologie: Toegepast en Beleidsonderzoek', en de Research Master 'Social and Cultural Sciences' (in samenwerking met Antropologie \& Ontwikkelingsstudies (CAOS) en Communicatiewetenschappen $(\mathrm{CW}))^{2}{ }^{2}$ Elk van deze opleidingen heeft een sterk onderzoeksgericht karakter met veel aandacht voor onderzoeksmethoden. Uitgedrukt in EC is dit bijvoorbeeld 36 van 180 EC in de Bachelor, exclusief wetenschapsfilosofie en de methodische elementen in onder andere 'integratiecursussen'.

Het gender- en seksualiteitsstudiesonderwijs is ondergebracht in het Institute for Gender Studies (IGS). Tot voor kort was het IGS een onafhankelijk interdisciplinair instituut. Op het moment van schrijven bestaat het IGS niet meer als zelfstandig instituut. De stafleden zijn bij de disciplinaire afdelingen ondergebracht, maar het interdisciplinair keuze-onderwijs wordt gecontinueerd. De algemene leerstoel vrouwenstudies is opgeheven en per 1 april 2016 is een leerstoel Gender and Diversity Studies ingevuld die is ingebed in het Nijmegen Institute for Social and Cultural Research, waaronder ook het sociologie-onderzoek valt. Het IGS kent haar oorsprong in 1974 met de oprichting van de projektgroep 'Emancipatie en Socialisme' bij het Derde Wereld Centrum en werd geformaliseerd in 1984 toen het Centrum voor Vrouwenstudies werd opgericht (CvV; later omgedoopt tot IGS). Het $\mathrm{CvV}$ was gekoppeld aan de centrale interfaculteit en de faculteiten der letteren, godgeleerdheid, en sociale wetenschappen, en bood (en biedt) interdisiciplinair genderstudies onderwijs aan. Voor sociologiestudenten is dit in de gehele geschiedenis keuzeonderwijs geweest. Specifieke initiatieven binnen de sociologie leken in de jaren 70 en 80 vanuit de studenten te komen en door de studenten gedragen te worden. In deze vorm werd er onder andere door studenten in de Vrouwengroep Sociologie gesproken over onderzoeksmethoden, het verbeteren van de studie-inhoud, en over concrete werken, waaronder Ann Oakleys The Sociology of Housework en de Paarse Nota van de vrouwenstudies groep aan de UvA (Alkemade \& Koolen, 1984; CvV, 1985).

De groep werd ondersteund door enkele student-assistenten en kreeg het voor elkaar dat de subfaculteitsraad bij gelijke geschiktheid voorrang zou geven aan vrouwelijke benoemingen, maar niet dat er specifieke plekken werden gecreëerd voor sociologen die werken vanuit feministisch perspectief. Uiteindelijk werd er begin jaren 80 in thematiekcursussen enige aandacht besteed aan seksisme en kon men in een tweedejaarsmethode- 
cursus de projectspecialisatie vrouwenstudies kiezen. Tevens was er een zelfstandig keuzevak Inleiding Vrouwenstudies in de Sociale Wetenschappen (Alkemade \& Koolen, 1984). Een terugkerende spanning in de strijd om meer aandacht voor vrouwenstudies was of het wel of niet mogelijk was om vrouwenstudies te bedrijven binnen de bestaande wetenschap en de bestaande structuren. Alkemade \& Koolen (1984:70) geven aan dat dit meningsverschil ten koste is gegaan van de strijdkracht van de vrouwenstudies en halverwege de jaren 80 leek de strijdbaarheid, mede door de successen, grotendeels verdwenen. ${ }^{4}$

Een belangrijk element hier is dat er dus in de vroege periode van de vrouwenstudies nimmer onderwijsstaf is geweest die vanuit feministisch perspectief werkte en was ingebed in de formele structuur. De initiatieven kwamen vanuit de studenten. Na de Nijmeegse omslag naar de 'verklarende' empirische-kwantitatieve sociologiestroming eind jaren 80 blijft deze situatie onveranderd. Het is in die stroming waarin de huidige opleidingen Sociologie geplaatst kunnen worden en waarvan we hier een beschrijvende analyse zullen geven.

\subsection{Studenten}

Als achtergrondinformatie bespreken we kort enkele man-vrouwverschillen in studentenaantallen. Tabel 1 bevat een selectie van kerngetallen. Deze cijfers tonen dat grofweg een derde van de bachelorstudenten man is en twee derde vrouw. De instroom is wat meer gelijk verdeeld (en was dat in voorgaande jaren nog meer), maar meer mannen lijken hun studiekeuze te heroverwegen. Van de mensen die de opleiding afronden lijkt er geen verschil in studieduur. In de Master Sociologie nemen meer mannen deel dan vrouwen, wat mogelijk samenhangt met de sterkere instroom van vrouwen in de research master.

\section{Tabel 1 kengetallen mannen en vrouwen in studentenpopulatie RU}

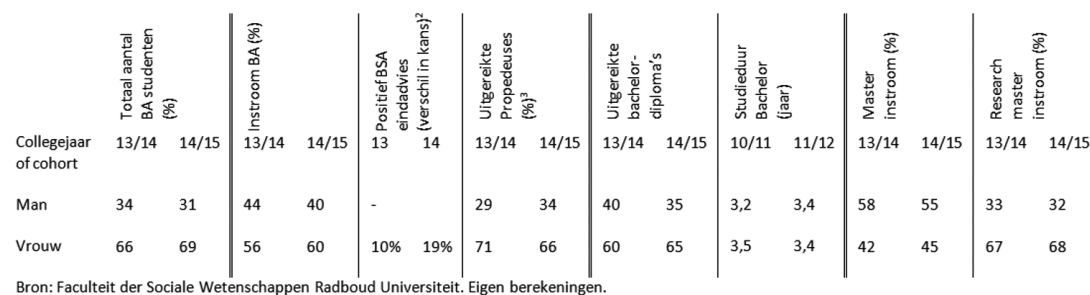

Bron: Faculteit der Sociale Wetenschappen Radboud Universiteit. Eigen berekeningen.

Noten: (1) dit betreft enkel de studenten die sociologie als hoofdstudie volgen; (2) de kans op een positief BSA voor vrouwen gedeeld door de kans op een BSA voor mannen - dit zijn dus geen procentpunten, met andere woorden: het is niet zo dat in 2013 mannen $80 \%$ slaagde en onder vrouwen $90 \%$, dat is in procenten $13 \%$ en in procentpunten 10 procentpunten; (3) dit omvat ook studenten die in eerdere jaren begonnen zijn met hun studie en studenten van wie sociologie niet de hoofdstudie is. 


\section{$2.2 \quad$ Eindtermen en omschrijvingen}

Voor geen enkele opleiding bevatten de doelstellingen en eindtermen een directe vermelding van gendervraagstukken of een genderperspectief, maar gezien het algemene karakter van deze teksten is dat niet verrassend. Wel verwijzen de einddoelen naar drie deelterreinen van de sociologie ongelijkheid, cohesie, rationalisering - en specifieke theorieën op de deelterreinen. Genderthema's zoals genderongelijkheid, gendernormen en seksuele vrijheid zijn direct verwant aan deze deelterreinen, en daarmee bieden de eindtermen dus ruimte voor gendervraagstukken en een genderperspectief. $^{5}$

Aankomende studenten kunnen bij de specifieke specialismen van de onderzoekers zien dat er aandacht is voor gendervraagstukken en manvrouwongelijkheid, ${ }^{6}$ maar dit wordt niet expliciet genoemd in de omschrijving van de opleidingen op de website. ${ }^{7}$

\subsection{Het bachelorcurriculum}

Gender in het verplichte bachelorcurriculum kent vooral de vorm van gender als thema. De eerstejaars bachelorstudenten sociologie aan de RU starten met een selectie aan maatschappijwetenschappencursussen. De sociologie wordt daarbij vertegenwoordigd door 'Hoofdvragen van de sociologie' (ook voor eerstejaars CAOS en CW) en 'Sociologische vraagstukken'. De korte cursusbeschrijvingen verwijzen niet direct naar socio-economische man-vrouwongelijkheid, maar het is een integraal onderdeel van deze cursussen; het lesboek dat sinds jaar en dag gebruikt wordt (i.c Ultee, Arts \& Flap, 2003) besteedt er bijvoorbeeld een volledig hoofdstuk aan, er zijn specifieke colleges over het thema, en gedurende de cursus komen gendervoorbeelden uit de actualiteit aan bod. Van de andere drie niet-methodecursussen in het eerstejaarscurriculum, behandelen twee er gendervraagstukken. In 'Maatschappelijk vooroordelen' worden houdingen ten opzichte van homoseksualiteit alsook transgenderemancipatie besproken. Waar dat niet in de studiegids vermeld wordt, vermeldt deze voor Social Inequality wel dat er naar ongelijkheid tussen mannen en vrouwen wordt gekeken en in het verklaringskader is er aandacht voor normen en instituties.

Het tweede en derde bachelorjaar tonen een vergelijkbaar beeld: in vijf van de zeven standaard theoretisch-empirische sociologiecursussen komen gendervraagstukken voor in de thematiek; bij één cursus staat het expliciet in de studiegids, bij de andere vier niet, alhoewel twee wel van gezin en familieleven spreken. In 'Leefstijlen: seksualiteit, cultuur en media' wordt gekeken naar houdingen ten opzichte van abortus, onge- 
huwd samenwonen en homoseksualiteit, aldus de studiegids. 'Opvoeding en deviant gedrag', 'Hedendaagse sociologische theorieën' en 'Life Course Research in Perspective' behandelen thema's als gendernormen en de gegenderde maatschappelijke rolverdeling. Een deel van de voorgeschreven artikelen focust op genderongelijkheid in arbeidsloopbaan, politiek en deviant gedrag. Ten slotte, in de verbredende cursus 'Beleidssociologie' figureert de openstelling van het huwelijk voor paren van gelijk geslacht als hoofdvoorbeeld van een beleidsproces, en studenten voeren een beleidscasestudie uit waarbij sommige groepen respectievelijk vrouwen-, LHB $^{8}$ en transgenderemancipatie onderzoeken.

Het methodeonderwijs omvat zowel beginnende als geavanceerde methoden, met nadruk op statistisch onderzoek. Daarbij worden technieken gedoceerd die nuttig zijn voor genderonderzoek, zoals interactie-effecten, maar dit wordt niet expliciet gekoppeld aan genderconcepten als intersectionaliteit (vgl. Spierings, 2010; 2012). De cursus wetenschapsfilosofie sluit aan op deze methodelijn met de nadruk op wetenschapsfilosofen als Popper, Kuhn en Lakatos. De fundamentele genderkritiek op deze meer positivistische benadering wordt niet expliciet besproken, evenmin als de feministische empiristische positie die epistemologisch aansluit bij deze benadering - en statistisch onderzoek - maar desalniettemin feministische kritiek levert op de androcentrische bias in de concrete toepassing van deze methoden (Harding, 1997). In keuzevakken als Introductory Gender Theories en Advanced Gender Theories komen deze debatten wel aan bod.

Er is ruime keuzevrijheid om onderzoek te doen naar emancipatie, genderongelijkheid en man-vrouwverschillen bij het schrijven van papers, in projectvakken en in de stage. Dergelijke invulling hangt veelal af van de eigen voorkeur van studenten. Bijvoorbeeld, voor 'Stage: arbeidsmarktoriëntatie' (15EC) kunnen studenten stage lopen bij tal van organisaties, zolang ze daar onderzoek verrichten. Zo liep afgelopen jaar een student stage bij Atria -kennisinstituut voor emancipatie en vrouwengeschiedenis, onderzoek en beleidsadvies- en deed onderzoek naar de ondervertegenwoordiging van vrouwen in de lokale politiek.

De bacheloropleiding bevat bovendien een keuzeminor (18EC) waarin niet alleen gender als thema, maar ook gender als perspectief aangeboden wordt. Middels de studiegids reikt de opleiding zelf 7 minores aan die zonder extra instroombeperkingen te kiezen zijn. Eén van deze minores is de minor 'Gender, Cultuur en Maatschappij' aangeboden door het Institute for Gender Studies (IGS), deze minor bevat heel helder ook kennisoverdracht van gender als perspectief. Gender als perspectief komt vanaf collegejaar 2016/2017 ook voor in de keuzeminor Beleidsonderzoek die 
door de opleiding sociologie zelf wordt aangeboden, aangezien één van de drie cursussen in deze minor de nieuwe cursus Gender and Diversity zal zijn. Voor de studenten met hoge cijfers is er tevens de optie om een honours programme te lopen in het tweede en derde jaar, waarbij een staflid sociologie in 2015/2016 de cursus 'Sluier der onwetendheid: Islam en Vrouwen' aanbiedt, waarin gender zowel als thema en perspectief wordt besproken.

\subsection{De (research) masters en summer school}

Ook in het vaste masterprogramma komt gender enkel als thema terug. Het masterprogramma bestaat voor de helft uit een scriptie en stage, waarbij studenten kunnen kiezen uit aangeboden projecten. Daarnaast volgen masterstudenten twee cursussen over het doen en rapporteren van beleidsonderzoek en drie thematische cursussen. Eén van die drie is 'Werk, gezin en gezondheid' waarbij de studiegids melding maakt van vijf uit te werken thema's, waaronder: (1) Werkende moeders, zorgende vaders; (2) Combineren van werk en gezin: druk druk druk?; en (3) Mantelzorg. De andere twee cursussen bevatten geen vaste onderdelen over gendervraagstukken.

Gevorderde bachelor- en (research) masterstudenten en PhD's kunnen ook facultatief en tegen betaling van inschrijfgeld deelnemen aan de summer course "Gender: a Core Concept in Society and Science" aan tijdens de internationale Radboud Summer School, die wordt verzorgd door de sociologiestaf in samenwerking met het IGS sinds 2015. Hierin worden genderconcepten en -theorie besproken en toegepast op thema's als onderwijs, arbeidsmarkt en politiek - kortom zowel de thematiek als het perspectief komen aan bod.

\subsection{Bespiegeling: Gender als thema}

Op basis van de beschrijving hierboven kunnen we enkele patronen observeren.

\section{(a) Een thema of een theorie?}

Gendervraagstukken worden in alle onderdelen van het sociologieonderwijs besproken als thema. Daarbij ligt de focus op man-vrouwongelijkheid en houdingen ten opzichte van gendergelijkheid en seksuele diversiteit. Zowel sociologische oorzaken als consequenties van deze posities en houdingen komen aan bod. Bij de oorzaken wordt ook aandacht aan normen en instituties besteed, wat in overeenstemming is met de gelaagdheid van het concept gender en waarbij het onderwijs dus ook een biologische ver- 
handeling van manvrouwverschillen overstijgt. Daarbij is er in de Master Sociologie ook expliciet aandacht voor de positie van mannen in het gezin en hun rol in de opvoeding. Ten slotte is er in verschillende cursussen in het bachelorprogramma aandacht voor seksualiteit als thema.

Deze samenvatting is vervat in een vocabulaire dat thuis is aan genderstudies. Dat is echter niet hoe de gendervraagstukken gepresenteerd worden in het curriculum. Het begrippenkader van genderstudies (denk aan sociaal-constructivisme, heteronormativiteit, performativiteit, masculiniteit, intersectionaliteit) wordt niet tot nauwelijks gebezigd in het sociologieonderwijs, alleen in de interdisciplinaire genderminor en de sociologische summer course. Hierdoor is het voor studenten sociologie die geen specialistische genderkeuzevakken gevolgd hebben wellicht lastig om hun eigen kennis over gendervraagstukken te verbinden aan de genderstudiesliteratuur waarin een andere terminologie gebruikt wordt. In andere woorden, in het verplichte curriculum komt gender als thema duidelijk aan bod, maar een genderperspectief zal gezocht moeten worden in keuze- en extracurriculair onderwijs.

Dit onderscheid tussen thema en perspectief is belangrijk, daar een begrippenkader en theoretische achtergrond in de genderstudies ook kan helpen de verschillende behandelde gendervraagstukken bínnen de sociologieopleiding aan elkaar te verbinden en om met een kritische genderblik naar 'niet gender'-thema's en -onderzoek te kijken. Op een vergelijkbare manier kan een gender perspectief ook bijdragen aan een meer interdisciplinaire oriëntatie van studenten. Genderstudies en haar begrippenkader helpt met het verbinden van onderzoek van (gender)psychologen, (gender)sociologen, (gender)politicologen, (gender)antropologen, (gender)economen et cetera. Daar gender raakt aan alle kernthema's van de sociologie heeft juist een fundament in genderstudies voor sociologen de potentie een brug te slaan naar andere sociale wetenschappen.

\section{(b) Integratie maakt geen verankering}

Zoals gezegd, komen gendervraagstukken ruim aan bod in de sociologieopleiding. Impliciet vormen gendervraagstukken ook onderdeel van de kernthema's van de sociologie waarnaar in de eindtermen van de opleidingen verwezen wordt. Alhoewel gendervraagstukken dus niet expliciet in de eindtermen van de opleidingen genoemd worden, staan ze wel expliciet genoemd in de studiegids bij verschillende cursussen en in ten minste evenzoveel cursussen komen gendervraagstukken aan bod zonder dat ze zo benoemd worden.

Deze kaders bieden docenten en studenten de mogelijkheid om de ge- 
genderdheid van de hoofdthema's van de sociologie te doceren en onderzoeken op een geïntegreerde manier. En dit gebeurt in zekere zin ook. Deze flexibiliteit en integratie ${ }^{9}$ brengen echter ook risico's met zich mee voor de aanwezigheid van gender in het sociologieonderwijs (Chow, 1985). In de eerste plaats, is de invulling van de grote lijnen afhankelijk van de keuzes die docenten maken, wat vaak ook samenhangt met hun eigen onderzoeksinteresses. Voor de continuering van de behandeling van gender als thema, laat staan als perspectief, in het onderwijs is het dan ook van belang dat er in het personeelsbeleid expliciet rekening wordt gehouden met de aanwezigheid van stafleden met een genderexpertise. Ten tweede, zullen studenten bij de invulling van hun keuzeruimte zich deels laten leiden door hun referentiekader en de mate waarin ze de koppeling tussen hun eigen studie en die van de keuzevakken zien. Een gedeeld vocabulaire of een beperkte introductie in een aangrenzend veld kan daarbij helpen. In andere woorden, zelfselectie is waarschijnlijk: studenten zonder bestaande interesse in gendervraagstukken raken niet snel bekend met het thema of begrippenkader en zullen gender en/of seksualiteit niet als steeds terugkomen analytische categorie beschouwen waardoor ze ook minder geneigd zullen zijn om hun keuzeruimte (deels) met genderonderwijs te verrijken.

\section{$3 \quad$ Universiteit van Amsterdam}

De UvA biedt drie opleidingen aan verzorgd door de afdeling Sociologie: de Bachelor 'Sociologie', de Master 'Sociologie' en de Research Master 'Social Sciences' (in samenwerking met onder andere politicologie en antropologie). Sociologie heeft bovendien zes minors en in een samenwerkingsverband met politicologie biedt het de Minor 'Gender and Sexuality' aan. Tevens kent de afdeling de eenjarige masteropleiding 'Gender, Sexuality and Society', met een sterke onderzoekscomponent (in EC vormt onderzoek bijna de helft van de totale Master: 29 van 6o EC). Zowel in de minor als in de Master wordt actuele problematiek rondom gender en seksualiteit behandeld. Dit vindt ook zijn weerslag in de eindpapers en masteronderzoeken waarin veelvuldig maatschappelijk relevante vraagstukken worden onderzocht, waaronder prostitutie, transseksualiteit, heteronormativiteit, seksueel geweld, vaderschap en ouderverlof en meer. 


\subsection{Studenten}

Net als in Nijmegen zien we dat over het geheel genomen er meer vrouwen zijn die sociologie studeren dan mannen aan de UvA: de gemiddelde verhouding op basis van bachelorjaarcijfers is $44 \%$ mannen en $56 \%$ vrouwen. Vrouwen studeren gemiddeld vaker én sneller af dan mannen, met een verschil van gemiddeld enkele procentpunten. ${ }^{10}$ Kijken we specifiek naar genderstudies dan is het merendeel van de studenten in de minor en master vrouw. Ook is er een groeiende belangstelling bij studenten voor gender- en seksualiteitsonderwijs in de laatste jaren, in het bijzonder naar de hoofdvakken van de minor en de masteropleiding (zie Tabel 2).

Tabel 2 studentaantallen in cursussen genter- en seksualiteitsstudies UVA

\begin{tabular}{|c|c|c|c|c|c|c|c|c|c|c|c|}
\hline & \multicolumn{6}{|c|}{ Bachelor } & \multicolumn{5}{|c|}{ Master } \\
\hline & 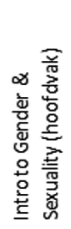 & 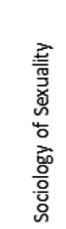 & 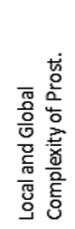 & 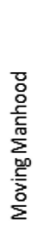 & 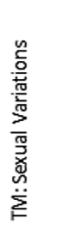 & 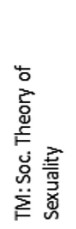 & 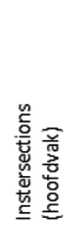 & 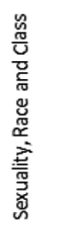 & 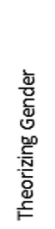 & 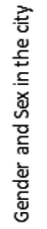 & 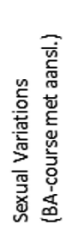 \\
\hline $2013-2014$ & 46 & n.v.t. & 47 & 24 & n.v.t. & 36 & 23 & n.v.t. & 16 & 21 & n.v.t. \\
\hline 2014-2015 & 52 & 24 & 46 & 32 & 33 & n.v.t. & 29 & 25 & 24 & 23 & 3 \\
\hline 2015-2016 & 72 & 17 & 43 & 39 & & & 32 & n.v.t. & 1 & & \\
\hline
\end{tabular}

De stijgende aantallen studenten die de keuzevakken volgen tonen aan dat het genderonderwijs veel studenten aanspreekt. Gender en seksualiteitsstudies plaatst de academische discussie over sociale constructies in een sociale en politiek context en verbindt de universiteit met de realiteit waar veel studenten dagelijks mee te maken hebben. In dat licht, lijkt voor de UvA de reputatie van Nederland, en in het bijzonder van de stad Amsterdam, als tolerant land met een liberaal beleid ten aanzien van gender en seksualiteit, juist ook veel buitenlandse studenten aan te trekken.

\subsection{Eindtermen en omschrijvingen}

Om te onderzoeken in welke mate en op welke wijze aandacht wordt besteed aan gender en seksualiteit, als thematiek dan wel als perspectief, hebben we alle vakomschrijvingen en modulehandleidingen per vak van de bachelor sociologie aan de UvA nagelopen en bekeken of er specifieke aandacht wordt gegeven in de basis-, verdiepings- en thematische modu- 
les. Geconcludeerd kan worden dat vraagstukken aangaande genderongelijkheid ruim aan bod komen in de sociologieopleiding, vooral met betrekking tot de onderwijs en arbeidsmarkt. In mindere mate is er aandacht voor gender en geweld en de rol van gender in gezinsvraagstukken. Vraagstukken aangaande seksualiteit en de culturele duiding van seksualiteit, komen er bekaaid van af met minimale aandacht bij de module sociologische theorie 4 in het tweede jaar en volledige aandacht in de thematische modules, zoals het vak 'Sexual Variations'. Het ontstaan van gender studies is aan de UvA nauw verweven met seksualiteitsstudies. Het betreft hier zowel de culturele duiding van sekse alsook van seksualiteit. In de tekst die volgt zullen we daarom regelmatig meer inzoomen op seksualiteitsstudies en dat dan expliciet maken.

\subsection{Het bachelorcurriculum}

De UvA bacheloropleiding kent vijf specialisaties: burgerschap, zorg en beleid; arbeid, organisatie en instituties; cultuursociologie; stadssociologie en onderwijsstratificatie; en levensloop. Gender komt dus niet als zelfstandig thema voor in de basisstructuur van het onderwijs. Aandacht voor gender- en seksualiteitsvraagstukken zit niet besloten in de structuur van de vakken van de vijf specialisaties, noch wordt het genoemd in de doelstellingen en eindtermen van de vakken in de opleiding, met uitzondering van de vakken in de minor 'Gender en Seksualiteit'. Alhoewel bij sommige vakken gender of genderongelijkheid wel wordt genoemd in de beschrijvingen, blijkt dit niet uit de voorgeschreven literatuur, zoals bijvoorbeeld in de basismodule 'Burgerschap, Zorg en Beleid'. Ook op de opleidingswebsite wordt meestal niet gesproken over gender- of seksualiteitsvraagstukken. Bovendien, zoals hieronder beschreven wordt, omvat het verplichte curriculum alleen onderwijs met gender als thema.

Vraagstukken rondom genderongelijkheid komen echter ruim aan bod binnen de verschillende modules, vooral met betrekking tot onderwijs en arbeidsmarkt. In mindere mate is er aandacht voor gender en geweld en gender in gezinsvraagstukken. Evenals in Nijmegen zien we hier ook dat gender in het reguliere curriculum van sociologie voornamelijk als een beschrijvende, empirische categorie wordt gebruikt: als thema en niet als concept. In het vak 'inleiding Sociologie' bijvoorbeeld krijgen thema's met betrekking tot gender in twee weken aandacht, zoals bijvoorbeeld patrileneariteit en matrilenariteit en arbeidsparticipatie van vrouwen, waarbij deze aandacht voornamelijk een empirisch karakter heeft en geen theoretische inbedding kent. Aan de ene kant wordt in dit onderwijs erkend dat gender niet hetzelfde is als sekse, aangezien er aandacht is voor culturele 
en structurele verklaringen voor verschillen tussen seksen. Aan de andere kant wordt er geen genderperspectief gehanteerd dat focust op betekenisgeving, zoals de betekenis van sekseverschillen, de relatie tussen biologie en cultuur, de normatieve reguleringen die genderrollen en machtsongelijkheid voortbrengen en in stand houden en de hierarchische ordening van mannelijkheid en vrouwelijkheid in een binair systeem. Voor vraagstukken aangaande seksualiteit is er minimale aandacht bij de cursussen 'Sociologische Theorie', maar uitgebreide aandacht in thematische modules en keuzevakken.

Tot twee jaar geleden werd in Sociologische Theorie 1: de Klassieken (BA1) een college gewijd aan Feministen in de Klassieken en meer specifiek Simone de Beauvoir. In Sociologische Theorie 4 (BA3) werd gender behandeld als perspectief en las men Judith Butlers Bodies that Matter. Deze cursussen wordt echter niet meer in die vorm gegeven en daarmee is ook de behandeling van gender als perspectief uit het vaste curriculum verdwenen. In het eerste jaar komen gender en seks daardoor slechts zijdelings ter sprake gerelateerd aan huwelijk, gezin en kinderen, waarbij seksualiteit bovenal wordt gekoppeld aan reproductie. Ook wordt de arbeidsmarktparticipatie van vrouwen aangestipt. In het huidige onderwijs vormen gender en seksualiteit geen hoofdonderwerp van een college meer, maar worden ze als een subthema behandeld, waardoor gender en seksualiteit niet als analytische categorieën in het eerste jaar worden uitgediept. Daarbij lijkt de invulling van de subthema's afhankelijk van de docent en diens persoonlijke interesses binnen de sociologie. De nadruk ligt bovendien op vrouwen en opvallend genoeg omvat deze literatuur over vooral kwantitatieve studies. De verdiepingsstructuur in het tweede en derde jaar kan wel een genderinvulling hebben, zo wordt voor de thematische keuzemodules 'Sexual Variations' en 'Intersectionality of Gender' en 'the Local and Global Complexity of Prostitution' aangeboden en bestaat er een keuzevak 'Moving Manhood'.

Binnen genderstudies heeft gender niet alleen betrekking op de analyse, maar is gender ook van belang in de methodologie en de wijze waarop wetenschap wordt beoefend en bijdraagt aan de constructie van het sekse verschil. Als reactie op de positivistische onderzoeksmethoden gingen feministen op zoek naar een nieuw onderzoeksmodel waarin objectiviteit binnen wetenschappelijk onderzoek en de hiërarchische relatie tussen onderzoeker en onderzoeksobject worden bevraagd. Daarnaast kent genderstudies ook een kritiek op de androcentrische wetenschap en het mannelijk wereldbeeld dat als standaard wordt gehanteerd. Dit vereist een transformatie van conceptuele noties van objectiviteit, relativisme, rationaliteit 
en reflexiviteit (Harding, 1991: 12). Deze kritiek op de sociale wetenschap wordt, met uitzondering van het basis vak Inleiding methoden in het eerste jaar waarin deze kritiek kort wordt besproken, opmerkelijk genoeg niet consequent aan de orde gesteld. Indien dergelijke kritieken wel aandacht krijgen, zoals in het basisvak Inleiding methoden in het eerste jaar, komt dit door de persoonlijke invulling door de docent. In het tweede en derde jaar komt deze fundamentele kritiek op sociologie als wetenschapsbeoefening niet meer diepgaand aan de orde in het methodeonderwijs.

\subsection{De masters en summer school}

De sociologie-afdeling heeft een algemeen masterprogramma, waarin studenten onder andere vakken kunnen kiezen op het gebied van sociologie van gender en seksualiteit. Tevens wordt er een Engelstalige specialisatietrack aangeboden welke geheel gewijd is aan genderthema's en -theorieën: 'Gender, Sexuality and Society'. In deze master komt gender uitgebreid aan de orde als thematiek en als genderperspectief.

Sinds 1995 verzorgt de UvA een interdisciplinaire Summer school op masterniveau: 'Sexuality, Culture and Society'. Afgelopen zomer is de UvA tevens gestart met de drieweekse interdisciplinaire zomercursus 'Introduction to Sexuality Studies' voor bachelor studenten. Beide Summer schools trekken studenten uit alle hoeken van de wereld. Veel internationale studenten komen uit landen waar openlijk praten en discussiëren over seksualiteit een taboe is, en homoseksualiteit bijvoorbeeld verboden dan wel zeer geproblematiseerd is. Zo waren afgelopen zomer de studenten voor de zomercursus 'Introduction to Sexuality Studies' afkomstig uit onder andere Polen, Rusland, China, Iran, Oeganda en Egypte. Deze studenten ervaren het veelal als een intellectuele stimulans om openlijk over deze onderwerpen te kunnen praten, ze te onderzoeken en te bediscussiëren.

\subsection{Seksualiteitsstudies}

Een opvallend kenmerk van gender- en seksualiteitsstudies aan de UvA is de grote nadruk op seksualiteit, zowel in de minor als in het master programma 'Gender, Sexuality and Culture'. Deze aandacht voor seksualiteit als theoretisch concept binnen het genderonderwijs is vrij uniek. Net als bij gender wordt seksualiteit hier naast een empirische categorie ook toegepast als een analytisch concept of perspectief. Wat het bijvoorbeeld betekent om homo of biseksueel te zijn, is afhankelijk van lokale genderideologieën en instituten in een samenleving (religie, school, media, etc.) die ons informeren wat de normen zijn rondom seksualiteit en hoe wij die normen internaliseren. Een voorbeeld hiervan is het tweedejaars vak 'Soci- 
ology of Sexuality' waarin seksualiteit niet alleen wordt gedefinieerd als een identificatie als homo- of heteroseksueel, maar wordt beschouwd als een sociaal-culturele constructie die betekenis krijgt in een bepaalde culturele context en in relatie tot bepaalde vertogen. Dit houdt in dat er wordt onderzocht wat het betekent om bijvoorbeeld lesbisch te zijn in een land en hoe dit gereguleerd wordt door bijvoorbeeld de wetgeving of de gezondheidszorg.

\subsection{Bespiegeling: integratie als specialisatie}

Concluderend kan gesteld worden dat de aandacht voor gender en seksualiteit voornamelijk thematisch is en niet conceptueel en dat aandacht voor deze literatuur niet besloten ligt in het reguliere curriculum van sociologie. Studenten hebben wel keuze uit verdiepings- en thematische modules waar gender en seksualiteit volledige aandacht krijgen. De huidige situatie kan het best begrepen worden in het licht van de geschiedenis van genderstudies aan de UvA in het algemeen.

\section{(a) Van beweging tot integratie?}

De gebrekkige integratie van gender en seksonderwijs in het reguliere curriculum van sociologie onderwijs aan de UvA hangt deels samen met het ontstaan van wat destijds nog 'vrouwen-' en 'homostudies' heette. De studierichting 'vrouwenstudies' is in 1977 opgericht door studenten in overleg met docenten en universiteitsbestuur. Deze studierichting kwam op tijdens de feministische golf en vocht tegen het stereotype beeld van 'gefrustreerde feministen'. Een open klimaat, mede geschapen door bijvoorbeeld het alternatief linkse feminisme van de Dolle Mina's, maakt de opkomst van vrouwenstudies mogelijk. Vrouwenstudies moest geïntegreerd worden in de sociale wetenschappen en werd aangehaakt bij politicologie (De Vries, 2015; zie ook Bonjour, Mügge \& Roggeband in dit themanummer). In 1984 werd vrouwenstudies een reguliere afstudeerrichting met een eigen vakgroep en het Belle van Zuylen-onderzoeksinstituut werd opgericht.

Ondanks het feit dat de studierichting vanaf het begin grote aantallen studenten trok, kon dit onderwijs binnen de faculteit aanvankelijk maar op weinig waardering en erkenning rekenen. Het was te weinig academisch, zo werd gezegd. Een heet hangijzer was dat de initiators en de meeste docenten destijds niet gepromoveerd waren, en er aanvankelijk geen hoogleraren verbonden waren aan de studierichting. Vanaf 1980 ontwikkelt zich ook een tak homostudies bij sociologie als gevolg van persoonlijke inzet van individuen, zoals Gert Hekma, één van de grondleggers van homostu- 
dies aan de UvA destijds. Bovendien komt er geleidelijk ook meer aandacht voor mannen binnen de studierichting.

Kijkend naar sociologie, dan werd gender- en seksonderwijs vanaf de jaren 90 meer een onderdeel binnen de discipline, maar dan wel vooral als specialisatie naast het reguliere onderwijs. Dit uitte zich meer recent in de start van de masterspecialisatie in 2008 en rond 2011 raakte de minor en masterspecialisatie ingebed in de opleiding Sociologie, die al colleges over gender en seksualiteit gaf in de summer school. Vanaf dat moment wordt er ook over 'gender- en seksualiteitsstudies', niet alleen 'genderstudies' gesproken.

Zoals aangegeven is de integratie in het sociologiecurriculum afhankelijk van de inzet van individuele docenten. Naast de specifieke minor en master vindt de integratie in het curriculum momenteel maar mondjesmaat plaats. Als Petra de Vries, mede-grondlegger van vrouwenstudies aan de UvA, terugblikt constateert ze dat vrouwenstudies beter hadden moeten integreren: "We zijn als een bubbel aan politicologie blijven hangen." (De Vries, 2015: 106). Ondanks de grote aantallen studenten is de staf bij sociologie op het gebied van gender en seksualiteitsstudies onderbezet, blijkend ook uit een voortdurend wisselde groep tijdelijke krachten en promovendi die worden ingezet in het onderwijs, en ontbreekt er een hoogleraar die aan het programma is verbonden.

\section{Conclusie: een genderdrieslag op twee wankele poten}

Als we de twee casusstudies vergelijken vallen verschillende overeenkomsten op waarvan de voor- en nadelen te duiden zijn langs de drie genderonderwijsstrategieën die Chow zeer verhelderend onderscheidt: vergelijking, speciale behandeling en mainstreaming (1985); waarbij vergelijking samen lijkt te vallen met het behandelen van gender als thema, terwijl speciale behandeling ruimte biedt voor gender als perspectief, en mainstreaming betekent dat dit perspectief integraal onderdeel is van het onderwijs.

\subsection{Vergelijking: gender als thema}

Als eerste overeenkomst tussen de twee cases nemen we waar dat gender en seksualiteit voornamelijk als empirische categorieën aan bod komen in het reguliere curriculum en vaak niet onder het label 'gender', maar bijvoorbeeld onder de noemer 'man-vrouwongelijkheid'. Bovendien is het zo dat in het epistemologie- en methode-onderwijs feministische kritieken of 
een - minder radicaal - genderperspectief op kwalitatieve en kwantitatieve onderzoeksmethoden geheel ontbreekt. Deze thematische aanpak weerspiegelt de vergelijkingsbenadering ('comparison approach') welke als voordeel heeft dat aandacht wordt gevraagd voor de positie van vrouwen, de private sfeer en houdingen ten opzichte van emancipatie, en dat kennisoverdracht plaatsvindt over bijvoorbeeld de invloed van gendernormen en -socialisatie op de verschillende posities van mannen en vrouwen in de maatschappij. Het kan dan ook als verdienste van de vrouwenbeweging gezien worden dat deze specifieke vorm van inpassing van genderthema's in het Nederlandse sociologieonderwijs heeft plaatsgevonden aangezien de thema's in het verleden door vrouwenstudies op de agenda zijn gezet. Belangrijke risico's van deze benadering, Chow volgend, zijn dat vrouwen en mannen als singuliere entiteiten worden beschouwd en dat er weinig verdieping plaatsvindt. Zo raken studenten niet bekend met feministisch-wetenschappelijke kritieken, gender- en seksualiteitstheorieën (bijv. Wollstonecraft, de Beauvoir, Foucault, Butler, Crenshaw, Harding, Haraway) en theoretische concepten als mannelijkheid, vrouwelijkheid, heteronormativiteit, intersectionaliteit, en queertheorie. Dit zien we inderdaad ook terug in onze cases, en zoals Berkowitz e.a. (2010) opmerken, mag van studenten die in de breedte al een veelheid aan abstracte theorieën en concepten gepresenteerd krijgen, niet verwacht worden dat ze de weinig geillustreerde genderhiërarchieën en -concepten die terloops aan bod komen zelf internaliseren.

\subsection{Speciale behandeling: ruim keuzeonderwijs}

Voor een deel afwezigheid aan gender als perspectief in het verplichte onderwijs opgevangen door de tweede overeenkomst: beide universiteiten bieden een substantiële hoeveelheid specifiek genderonderwijs aan in de vorm van keuzevakken, minores, summer courses en masterspecialisaties. Dit volgt de speciale behandelingsbenadering ('special treatment approach'), waarvan Chow terecht opmerkt dat dit geen invloed heeft op een breed spectrum aan studenten, maar enkel op die studenten die al enige interesse in genderstudies hebben. Het voordeel van deze strategie is volgens haar wel dat er diepgaande kennis door studenten wordt opgedaan. De studenten die bereikt worden, wordt een belangrijk theoretisch kader geboden waarbinnen verschillende vormen van sociale ongelijkheid en de onderliggende machtsmechanismen die deze ongelijkheid in stand houden, kunnen worden onderzocht. De koppeling tussen deze multidisciplinaire keuzevakken in genderstudies en het vast curriculum sociologie is echter wel helderder voor studenten als ook in de opleiding sociologie 
reeds een genderlens is gehanteerd in het analyseren van de sociale structuren en processen (e.g. Acker, 1999). Noemenswaardig, aangaande deze onderwijsstrategie is dat beide cases een duidelijke groeiende populariteit van (interdisciplinaire) genderstudies keuzevakken onder studenten laten zien.

In de interdisciplinaire keuzevakken is juist ook plaats voor het bieden van vernieuwde inzichten door buiten het eigen vaste kader te kijken. De studenten leren daarbij kritisch na te denken over de normen en vanzelfsprekendheden in hun eigen discipline en een eigen positie in te nemen. In het bijzonder in het interdisciplinaire genderonderwijs is er continue ontmoeting tussen onderzoekstradities en veel expliciete aandacht voor de waarde en tegenstellingen tussen verschillende onderzoeksmethoden. Hiermee biedt juist genderonderwijs interessante mogelijkheden voor een samenvoeging en verdere ontwikkeling van een combinatie van kwantitatieve en kwalitatieve onderzoeksmethoden, bijvoorbeeld binnen mixed methods onderzoeksprojecten rondom gendervraagstukken.

\subsection{Mainstreaming: geen ingebed perspectief}

Ten slotte valt in beide casestudies op dat het doceren van genderthema's (of zelfs enige aspecten van een genderperspectief) binnen het vaste curriculum afhankelijk lijkt te zijn van de individuele docenten, aangezien het onderwerp niet verankerd is in de opleidingen. Dit resoneert met de observatie van Chow aangaande de mainstreaming strategie waarbij de productie en reproductie van genderhiërarchieën expliciet zou moeten worden geconceptualiseerd als integraal onderdeel van de hoofdvragen van de sociologie. Dit is veeleisend en kan enkel slagen als er volledige steun is onder de onderwijsstaf, wat vaak op gespannen voet staat met de academische vrijheid van docenten. Deze strategie lijkt het krachtigst, maar roept ook het meest institutionele weerstand op, wat de andere twee strategieën aantrekkelijk maakt, aldus Chow (1985: 310). Die institutionele weerstand is in de historische bronnen die we raadpleegden wel naar voren gekomen, maar we hebben niet concreet onderzocht of in de hedendaagse situatie deze weerstand er nog is en welke vorm deze aanneemt, wat de verklarende vraag boven brengt. Zoals aangegeven in de introductie ligt deze vraag buiten het bereik van deze bijdrage, maar de descriptieve analyse hierboven en de inkadering in het schema van Chow bieden mogelijkerwijs wel een startpunt, waarbij de institutionele setting een belangrijke factor kan zijn. 


\subsection{Een genderdriepoot}

Blijven we meer bij de beschrijvende vraag en beredeneren we vanuit de assumptie dat het wenselijk is dat sociologiealumni een sterk begrip hebben van de fundamentele rol die genderhiërarchieën spelen in onze maatschappij, dan zou in het bijzonder de integratie van een genderperspectief in het reguliere verplichte curriculum - Chows derde strategie - een krachtige verrijking zijn voor de sociologie. Daar een totale integratie van een gendersperspectief als unieke analytische lens, in alle onderdelen van het onderwijs, wellicht wat sterk utopisch gedacht is, kunnen we een dergelijke integratie ook als volgt concretiseren:

1 een verplichte introductie gendersociologie als onderdeel van het basis curriculum voor alle bachelor studenten sociologie, die hen bekendmaakt met de achtergrond, ontwikkeling en het vocabulaire van genderstudies en -sociologie, waardoor de analytische concepten van genderstudies een structureel onderdeel worden van het instrumentarium van sociologiestudenten;

2 het gebruik van gender en seksualiteit als thema en perspectief, of in andere woorden als empirische en analytische categorieën, in minimaal één algemene bachelorsociologiecursus per jaar, zodat student ook met het perspectief bekend raken. Hierbij kan bijvoorbeeld gedacht kan worden aan cursussen over sociale ongelijkheid en levensloopontwikkelingen; en

3 een uitgebreid keuze- en specialisatieaanbod voor studenten om zich verder te verdiepen in gender-, diversiteits- en seksualiteitsstudies middels bijvoorbeeld (interdisciplinaire) minores, master(specialisatie)s en summer courses.

\section{Noten}

1. Een verschil in de positie van gender in het onderwijs moet echter niet makkelijk toegedicht worden aan de verschillen in school; daarvoor is deze tweedeling lang niet zo eenduidig als hier gesuggereerd wordt en zouden per school meerdere cases onderzocht moeten worden.

2. Tenzij anders vermeld is de informatie van toepassing op het onderwijsprogramma van 2015-2016.

3. Inclusief deze cursussen loopt dit op tot meer dan 1/3de van het bachelorcurriculum.

4. Met dank aan Carla van Rooy (RU, IGS) voor het opdiepen van de historische informatie.

5. Bron: "Sociologie: Toetsing en Beoordeling" Radboud Universiteit Nijmegen, 14 maart 2014

6. Bron: http://www.ru.nl/sociologie/onderzoek/kopie-medewerkers/20150923 
7. Bijvoorbeeld: www.ru.nl/sociologie/onderwijs/aankomende-studenten/

8. Lesbisch, Homo en Biseksueel

9. Men kan hier ook denken aan mainstreaming, maar om dat label te gebruiken zou sprake dienen te zijn van een bewuste en integrale integratie in alle onderdelen en lagen van het onderwijs (zie Verloo, 1998).

10. Cijfers gelden voor voltijdstudenten met een VWO vooropleiding, aldus berekend op basis van cijfers uit de studentenadministratie van de UvA, waaronder tabellen "Analyse studenten UvA" (sociologie) en "Rendement bachelor" (sociologie; uitgesplitst naar vrouw en man). Met dank aan Siebert Wielstra, onderwijsassistent sociologie.

\section{Bibliografie}

Acker, J. (1999). Gender and organizations, in Chafetz, J.S. (ed.) Handbook of the sociology of gender, New York, p. 177-194.

Berkowitz, D., Manohar, N.N. and Tinkler, J.E. (2010). 'Walk Like a Man, Talk Like a Woman Teaching the Social Construction of Gender.' Teaching Sociology, 38(2): P132-143.

Chow, E.N.L. (1985). 'Teaching sex and gender in sociology: Incorporating the perspective of women of color.' Teaching Sociology 12(3): 299-311.

$\mathrm{CvV}$ - Centrum voor Vrouwenstudies, Katholieke Universiteit Nijmegen (1985). Jaarverslag 1985.

El, C. Van (2002). Figuraties en verklaringen. Stijlgebonden schoolvorming in de Nederlandse sociologie na 1968. Aksant.

Gerring, J. (2007). Case Study Research; Principles and Practices. Cambridge UP.

Harding, S. (1991). Whose science? Whose knowledge? Thinking from women's lives. Ithaca: Cornell University Press.

Harding, S. (1997). 'Is there a feminist method?' In S. Kemp \& J. Squires (Eds), Feminisms (p. 160170). Oxford: Oxford University Press.

Schabel, P. (2002). 'Verklaren en begrijpen'. NRC. 8 juli. http://www.nrc.nl/handelsblad/2002/07/ 6/verklaren-en-begrijpen-7597242

Scott, J. (2013). 'The Uses and Abuses of Gender,' Tijdschrift voor Genderstudies 16(1): 63-77.

Smollenaars, E. (2005). 'De sociologie gelooft weer in zichzelf. NRC. 2 mei. http://vorige.nrc.nl/ wetenschap/article1679183.ece

Spiering, H. (1997). 'Weg met de holle frasen; Socioloog Wout Ultee wil alles toetsen', in NRC. 11 oktober. http://www.nrc.nl/handelsblad/1997/10/11/weg-met-de-holle-frasen-socioloogwout-ultee-wil-alles-7371401

Spierings, N. (2010). 'Een nieuwe kijk op kwantitatieve methoden in feministisch onderzoek,' Tijdschrift voor Genderstudies, 13(3): 32-44.

Spierings, N. (2012). 'The inclusion of quantitative techniques and diversity in the mainstream of feminist research,' European Journal of Women's Studies, 19(3): 331-347.

Ultee, W., W. Arts en H. Flap (2003). Sociologie. Vragen, Uitspraken, Bevindingen (3e editie). Martinus Nijhof.

Verloo, M. (1998). Gender mainstreaming: conceptual framework, methodology and presentation of good practices. Final Report of Activities of the Group of Specialists on Mainstreaming (EG-S-MS).

Vries, P. de (2015). 'Atypisch: feminisme en vrouwenstudies', in Het F-boek. Houten: Spectrum. 


\section{Over de auteurs}

Niels Spierings is universitair docent politieke en gendersociologie aan de Radboud Universiteit (RU) sinds 2014. Daarvoor werkzaam aan de afdelingen sociologie van de LSE en University of Essex, en bij de afdeling politicologie aan de RU. Hij is gepromoveerd in de politicologie en economie aan de RU op de arbeidsparticipatie van vrouwen in Moslimlanden.

Marie-Louise Janssen is cultureel antropologe en sinds 2010 werkzaam als docent gender- en seksualiteitsstudies aan de afdeling sociologie aan de Universiteit van Amsterdam, en onderzoeker naar sekswerk, migratie en mensenhandel in Nederland. In 2007 is zij gepromoveerd aan de UvA op sekswerk en mensenhandel vanuit Latijns-Amerika naar Nederland. 
